Vol. 5, No. 1, Februari 2022 / P-ISSN: 2622-9862 / F-ISSN: 2622-707X

\title{
REFLEKSI MORALITAS GUGATAN ANAK TERHADAP ORANG TUA DI PENGADILAN DI TINJAU DALAM PERSPEKTIF HUKUM
}

\author{
Suyikati \\ Fakultas Hukum Universitas Widya Mataram \\ Jogyakarta, Indonesia \\ suyik_law@yahoo.co.id
}

\begin{abstract}
The essence of the relationship between children and parents in Law Number 1 of 1974 on Marriage, article 46 Paragraphs (1) and (2) does not provide legal certainty, considering that there are no articles that explain further about the form of parental care that must be carried out by children, the size of the child's maturity, and the legal consequences if you violate it. So that this regulation cannot run or cannot be fulfilled with certainty. The emergence of the problem of the phenomenon of the rise of lawsuits against parents in court cannot be separated from the decline in morality towards parents regarding the value of children's moral education in formal education and non-formal education in the child's environment, this problem is increasingly unstoppable with the absence of further legal policies as elaboration. Law Number 1 of 1974 concerning Marriage, Article 46 Paragraphs (1) and (2), so that it is clear that the rights of parents are protected and can put the position of parents in what should be desired by these provisions.
\end{abstract}

Keywords: Morality, Children, Lawsuit, Parents, Law.

\section{PENDAHULUAN}

Undang-Undang Dasar Negara

Republik Indonesia tahun 1945 dan Pancasila sebagai landasan negara ${ }^{1}$ mengambarkan kehadiran suatu Negara Indonesia yang merupakan negara yang memilih Pancasila sebagai falsafah yang merupakan landasan Negara dan menjadi landasan lahirnya hokum yang mana Hukum pada dasarnya harus selaras dengan nilai-nilai luhur bangsa yang di uraikan dalam pancasila itu sendiri.. Dalam implementasinya saat ini masih banyak peraturan perundang-undangan yang tidak sesuai dengan nilai-nilai luhur

\footnotetext{
${ }^{1}$ Roni Sulistyanto Luhukay, Penghapusan Izin Lingkungan Kegiatan Usaha Dalam Undang Undang Omnibus Law Cipta Kerja Jurnal MetaYuridis, No. P-ISSN : 2614-2031 / NO. E-ISSN : 2621-6450, Fakultas Hukum Universitas PGRI Semarang, hlm 101
}

bangsa Indonesia khususnya tidak adanya regulasi pembatasan gugatan terhadap orang tua yang di pandang Sebagian pihak memiliki nilai nilai yang bertentangan dengan falsafah bangsa Indonesia dan moralitas hukum ${ }^{2}$. Sejalan dengan hal ini Bellefroid menyatakan bahwa prinsip hukum merupakan suatu norma dasar yang dijabarkan dalam hukum positif dan berasal dari aturan-aturan yang lebih umum. Priinsip hukum itu merupakan pengendapan hukum positif dalam suatu 
masyarakat ${ }^{3}$ yang artinya suatu regulasi yang lahir sebagai pengendapan dari falsafah bangsa yang menjunjung nilai nilai luhur bangsa Indonesia yang kemudian di jadikan sebagai hukum positif.

Berbagai polemic muncul setelah hukum positif di Indonesia tidak mampu memberikan pondasi yang kuat yang berpotensi melunturnya nilai nilai luhur itu sendiri dapat di lihat dengan banyaknya kasus gugatan anak kepada orang tua di pengadilan. Jika mengupas secara mendalam mengenai adanya interaksi hubungan anak dengan orang tua yang semakin hari semakin renggang atau interaksinya semakin hari semakin memiliki jarak. Hal ini dapat di karenakan Kesibukan kerja orang tua yang cendrung meninggalkan anaknya serta pendidikan internal di dalam rumah berkurang, sehingga menyita seluruh waktu, tindakan ini memberikan contoh kepada anak itu sendiri ketika dia tumbuh besar menjdai dewasa dimana banyaknya pekerjaan membuat anak semakin kurang meluangkan waktu untuk orang tuanya yang telah memasuki usia senja. Sementara itu, agama telah menganjurkan, mendorong, bahkan mewajibkan pemeluknya untuk senantiasa patuh dan

\footnotetext{
${ }^{3}$ Notohamidjojo, Soal-Soal Pokok Filsafat Hukum, , Jakarta: Gumung Mulia , BPK,1975, hlm. 49
}

hormat, menjaga dan peduli kepada orang tua. Situasi tersebut akan mempengaruhi kualitas sikap mental anak masa kini, yang pada gilirannya menjadi penentu kualitas sumber daya manusia di masa yang akan datang $^{4}$ Perubahan masyarakat yang semakin berkembang mengakibatkan adanya perubahan pada hukum. perubahan tersebut mempengaruhi tata nilai di dalam kehidupan. Perubahan yang terjadi pada tata nilai ini menentang nilai yang lama atau perubahan baru itu menggulingkan tata nilai yang lama 5 .

Berbagai perubahan seiring terjadi di tengah masyarakat khusunya perilaku moralitas anak terhadap orang tua yang cendrung tidak menunjukan sikap ketidak pedulian terhadap orang tua yang melunturkan nilai nilai luhur bangsa Indonesia dan nilai nilai moralitas yang ada, jika di uraikan lebih dalam berbagai ketentuan mengatur hubungan timbal balik antara anak dan orang tua, diantaranya ketentuan Pasal 321 Kitab UndangUndang Hukum Perdata terdapat kewajiban timbal balik antara anak dan

4 Tedy Sudrajat, "Perlindungan Hukum Terhadap Hak Anak Sebagai Hak Asasi Manusia Dalam Perspektif Sistem Hukum Keluarga di Indonesia”, Kanun Jurnal Ilmu Hukum, Nomor 54, Tahun XIII Agustus 2011, hlm 123, diakses tanggal $16 \quad$ Oktober 2017, http://www.jurnal.unsyiah.ac.id/kanun/article/do wnload/6245/5150, diakses pada tanggal 24 juli 2021, pukul 16:30 wib.

5 Wahyu, Perubahan Sosial dan Pembangunan, Jakarta: PT Hecca Mitra Hutama, 2005,hlm 65 
orang tua dan sebaliknya. Selain itu pada prinsipnya, anak wajib menghormati orang tua dan mentaati kehendak orang tua, sebagaimana diatur dalam Pasal 46 Undang-Undang Nomor 1 Tahun 1974 tentang Perkawinan. Ketentuan-ketentuan tersebut sangat sumir sehingga kerap terabaikan oleh masyarakat. Terkait kelanjutusiaan orang tua, seorang anak tetap memiliki kewajiban setelah anak dewasa. Hal ini mengindikasikan bahwa anak tidak boleh memutuskan hubungan dengan orang tua ${ }^{6}$

Negara Indonesia memberlakukan peraturan-peraturan yang terkait dengan adanya tanggung jawab anak terhadap orang tua yang yang dituangkan dalam Undang-Undang Dasar Negara Kesaturan Republik Indonesia Tahun 1945 (UUD NKRI 1945), Kitab Undang-Undang Hukum Perdata (KUH Perdata), UndangUndang Nomor 1 Tahun 1974 tentang Perkawinan, Undang-Undang Nomor 13 Tahun 1998 tentang Kesejahteraan Lanjut Usia (UU KLU), Undang-Undang Nomor 23 Tahun 2004 tentang Penghapusan Kekerasan Dalam Rumah Tangga (UU PKDRT). Beberapa Peraturan Perundangundangan tersebut memiliki keterkaitan dengan isi daripada Pasal 46 Ayat (2)

6 Marcelia Oktavia Gosal Yuwono Prianto, Perlindungan Hukum Terhadap Lanjut Usia Yang Mengalami Kekerasan Psikologis Dan Finansial, Jurnal Era Hukum, Volume 2, No. 2, Oktober 2017, hlm 295
Undang-Undang Nomor 1 Tahun 1974 tentang Perkawinan, yakni jika anak telah dewasa, anak wajib memelihara menurut kemampuannya, orang tua dan keluarga dalam garis lurus keatas, bila orang tua memerlukan bantuannya $^{7}$ akan tetap kaidah hukum ini tidak dapat berjalan sebagaimana mestinya mengingat kaidah hukum atau peraturan tersebut harus memenuhi 3 (tiga) unsur yaitu berlaku secara yuridis, berlaku secara sosiologis, dan berlaku secara filosofis. Mungkin perlu diberlakukan sanksi tambahan untuk mempertegas keberlakuan Pasal 46 yang berunsurkan keberlakuan yuridis. Sanksi tersebut akan bersifat memaksa masyarakat agar tunduk pada Pasal 46 Ayat (1) dan (2) hal ini di karenakan adanya perubahan sikap dan perilaku sosial di tengah masyarakat dengan adanya perkembangan zaman untuk itu jika regulasi ini di terapkan pada tahun tahun sebelumnya mungkin akan relevan meskipun tidak meletakan konsekuensi hokum akan tetapi jika di berlakukan saat ini akan kurang efisien dan efektif ${ }^{8}$ Artinya untuk saat ini pasal ini memiliki kelemahan dari aspek mengenai penghormatan terhadap orang tua berpotensi anak dapat mengungat orang tua nya kapapun pun Ketika terjadi permasalahan.

\footnotetext{
${ }^{7}$ Ibid.,, hlm 307

${ }^{8}$ Ibid.,, hlm 311
} 
Bahkan akhir akhir ini banyak anak yang mengugat orang tuannya hal ini terjadi di Bandung. sejalan dengan hal ini Sonny Dewi Judiasih berpendapat bahwa, secara norma anak tidak diperbolehkan mengajukan gugatan kepada orang tuanya. Tindakan ini tidak sejalan dengan norma yang ditetapkan dalam Undang-undang Perkawinan. Artinya Undang-Undang Nomor 1 Tahun 1974 tentang Perkawinan mewajibkan seorang anak untuk menghormati orang tua serta wajib memelihara orang tuanya jika anak sudah dewasa akan tetapi fenomena kasus anak gugat orang tua merupakan contoh dari ketidaksesuaian norma dari UU Perkawinan. Jika dilihat, hampir sebagian besar kasus anak gugat orang tua didasarkan atas motif ekonomi, salah satunya terkait pembagian harta waris. ${ }^{9}$ Tidak hanya itu adapuan kasus anak menggugat ibu kandungnya di Garut sebesar Rp 1,8 miliar. Kasus yang sama dan masih hangat ditelinga adalah kasus Nenek Cicih yang juga digugat empat orang anaknya yaitu Ai Sukawati, Dede Rohayati, Ayi Rusbandi dan Ai Komariah terkait persoalan warisan tanah. Anak anak

\footnotetext{
${ }^{9}$ Sindonews, maraknya anak gugat orang tua di pengadilan dengan berbagai masalah ekonomi, Https://Daerah.Sindonews.Com/Read/313110/701/ Marak-Anak-Gugat-Orang-Tua-Dosen-UnpadSecara-Norma-Dan-Hukum-Tidak-Boleh1611558095, diakses pada tanggal 25 juli 2021 pukul 16:30 wib
}

menggugat Cicih secara perdata senilai $\mathrm{Rp}$ 1,6 miliar.

Selain itu adanya gugatan di Pengadilan Negeri Bandung gugatan anak terhadap orang tua, yaitu gugatan anak perempuan bernama Meymey (Oey Huei Beng) menggugat bapaknya Oey Tiauw Sioe yang sudah berumur 80 tahun lebih. Lebih mengkhawatirkan lagi, sang bapak yang digugat saat ini keadaannya tengah sakit keras kena serangan stroke. Oey Tiauw Sioe tidak bisa berjalan dan hanya terbaring di tempat tidur, bahkan untuk makan saja harus disuapi.. ${ }^{10}$

Jika di dalami hakikatnya Pada prinsipnya semua anak yang sudah dewasa adalah subjek hukum yang bebas melakukan perbuatan hukum dengan siapa pun, termasuk orangtuanya. Namun berdasarkan nilai moral hal ini dianggap tidaklah patut bagi seorang anak menggugat orangtua mengingat adanya hubungan timbal balik antara orangtua dan anak berupa hak dan kewajiban yang harus dipenuhi baik oleh orangtua kepada anak maupun anak kepada orangtua. Kewajiban anak kepada orangtua dengan anak menggugat orangtua merupakan suatu kontradiksi, namun apabila dikaji lebih

10 Fenomena anak gugat orang tua ke pengadilan dan bukti lunturnya moralitas, https://www.pikiran-rakyat.com/bandung-raya/pr01293982/fenomena-anak-gugat-orang-tua-kepengadilan-bukti-lunturnya-moralitas-420181, dikases pada tanggal 23 juli 2021, pukul 12:21 wib. 
lanjut berdasarkan nilai-nilai yang hidup dimasyarakat maka keduanya memiliki keterkaitan yang tidak dapat dipisahkan ${ }^{11}$

Undang-undang Perkawinan. Artinya Undang-Undang Nomor 1 Tahun 1974 tentang Perkawinan pasal 46 Ayat (1) dan (2) memiliki esensi tanggung jawab yang secara perdata mengikat antara anak dan orang tua, Tanggung jawab tersebut merupakan ciri manusia beradab (berbudaya). Manusia merasa bertanggung jawab karena telah menyadari akibat baik atau buruk perbuatannya itu, dan menyadari bahwa pihak lain memerlukan pengabdian dan pengorbanannya ${ }^{12}$ esensi ini tidak berjalan efektif di pengaruhi beberapa factor antara lain adanya esensi kebebasan serta hukum tidak mampu menjangkau hubungan privat sehingga tidak adanya regulasi penegasan terhadap regulasi ini. Jika regulasi ini di paksakan dapat berPotensi terjadinya Suatu kebijakan yang dilakukan menimbulkan obesitas hukum ${ }^{13}$ artinya pengaturan yang berlebihan urusan privat oleh negara,

11 Riska Andista Indriyani Anjar Sri Ciptorukmi Nugraheni, Kontradiksi Antara Kewajiban Anak Kepada Orangtua Dengan Anak Menggugat Orangtua, Jurnal Privat Law Vol. Vii No 2 Juli - Desember 2019, Hlm 284

${ }^{12}$ Supriadi, Etika dan Tanggung Jawab, Jakarta, Sinar Grafika, 2002, hlm 35.

${ }^{13}$ Roni Sulistyanto Luhukay,dan Jaelani, Abdul Kadir. Penataan Sistem Peraturan Perundang-Undangan Dalam Mendukung Penguatan Konstitusi Ekonomi Indonesia. Jatiswara, volume. 34, no. 2, july 2019. ISSN 2579-3071, hlm 158
Sejalan dengan hal ini Soerjono Soekanto, berpendapat bahwa efektif atau tidaknya suatu hukum ditentukan oleh 5 (lima) faktor, yakni faktor hukum, faktor penegak hukum, faktor sarana dan fasilitas penegak hukum, faktor masyarakat, dan faktor kebudayaan. ${ }^{14}$

\section{METODE PENELITIAN}

Penelitian ini mengunakan metode penelitian yuridis normative atau sering di sebut dengan penelitian studi kepustakaan yang menitikberatkan pada study undang undang dan berbagai referensi hukum. Sejalan dengan hal ini Philipus M Hadjon dan Tatiek Sri Djatmiati menyatakan penelitian hukum normatif selalu beranjak dari hakekat keilmuan hukum yang dilaksakan pada ilmu hukum ${ }^{15}$. Sejalan dengan itu Peter Mahmud Marzuki mengemukan bahwa penelitian hukum yang sering di sebut dengan Legal Research merupakan penelitian hukum yang mengunakan aspek aspek pendekatan, pendekatan perundang undangan (Statute Aprroach), dan aspek pendekatan konseptual (Conceptual Approach $)^{16}$ Dalam penelitian ini penulis

${ }^{14}$ Soerjono Soekanto, Faktor-Faktor yang Mempengaruhi Penegakkan Hukum , Jakarta, CV Rajawali, 1983,hlm 5

15 Philipus M Hadjon dan Tatiek Sri Djatmiati, Argumen Hukum, Surabaya, Gadjah Mada University Press, Cetakan Ke 7, 2016, hlm 3.

${ }^{16}$ Johnny Ibrahim, Teori dan Metodologi Penelitian Hukum Normatif, Malang, Banyumedia, 2010, hlm 93 
mengunakan pendekatan perundang undangan ( Statute Aprroach ), dengan menguraikan mengenai hierarki, dan asas asas dalam peraturan perundang undangan yang berlaku di indonesia ${ }^{17}$ serta mengunakan aspek pendekatan konseptual (Conceptual Aprroach), dimana penulis mencoba menguraikan konsep hukum dengan beranjak dari pandangan pandangan hukum para ahli dan doktrin doktrin yang berkembang didalam ilmu pengetahuan dan teknologi dalam berbagai referensi hokum.

\section{HASIL DAN PEMBAHASAN}

1. Esensi hubungan anak dan orang tua dalam Undang-Undang Nomor 1 Tahun 1974 tentang Perkawinan.

Bangsa Indonesia mencantumkan esensi bernegara dalam Pembukaan konstitusi Negara sebagaimana tertuang dalam Alenia Keempat UUD NRI Tahun 1945, yang secara tegas menjamin perlindungan segenap bangsa Indonesia dan seluruh tumpah darah Indonesia, tidak hanya itu ada esensi lain dalam upayah Negara memajukan kesejahteraan dengan mencerdaskan kehidupan bangsa, serta adanya upayah untuk melaksanakan ketertiban dunia yang dilandaskan pada kemerdekaan, perdamaian, dan

17 Peter Mahmud Marzuki, Penelitian hukum, Edisi Revisi, Jakarta, Kencana, 2005, hlm 136.

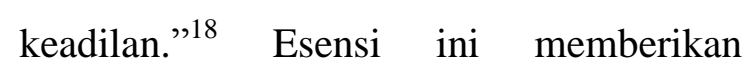
jaminan mengenai suatu bentuk perlidungan negara dan kesejahteraan negara, untuk itu undang undang ini memberikan Amanah untuk melahirkan regulasi di bawahnya dalam menjawab tujuan konstutusi tersebut. Jaminan perlindungan dilakukan bahkan dalam lingkup paling kecil yaitu keluarga yang di taungkan dalam Undang-Undang Nomor 1 Tahun 1974 tentang Perkawinan. Regulasi ini mengatur menganai perkawinan sampai pada kewajiban dalam perkawinan mulai dari kewajiban anak terhad orang tua dan orang tua terhadap anak, kewajiban suami dan istri dalam keluarga.

Dewasa ini dengan adanya perkembangan hukum, sosial, dan budaya masyarakat, tentunya regulasi perundang undangan yang mengatur mengenai Perkawinan membutuhkan pembaharuan guna mencapai titik penyempurnaan. Pembaharuan yang meletakan pada Penyempurnaan sangat urgen dilaksanakan mengingat dalam penyelenggaraan perkawinan ada yang tidak sesuai dengan yang diharapkan dari pembentukan regulasi perundang undangan Perkawinan itu sendiri. Hal tersebut antara lain terlihat dari adanya berbagai fenomena hukum peribahan sikap dan perilaku anak dengan

18 Naskah akademik Undang-Undang Nomor 1 Tahun 1974 tentang Perkawinan 
adanya perkembangan teknologi dan kehidupan sosial yang dimana regulasi ini belum mampu mengejar terjadinya perubahan tersebut. Banyak fenomena anak mengungat orang tuannya terjadi di karena banyak factor meskipun dalam dalam regulasi perundang undangan Perkawinan pasal 46 mengambarkan kelemahan regulasi sehingga diperlukan regulasi pendukung yang memperkuat atau belum adanya pembaharuan hukum dari regulasi penegasannya mengenai ketentuan tersebut. Untuk itu adanya konsistensi negara dalam menjamin penghormatan, pemenuhan, perlindungan, pemajuan, dan penegakan hak asasi manusia, tidak lepas dari pengaruh perkembangan hukum, sosial, dan budaya masyarakat yang bergerak secara dinamis. Salah satunya ditandai dengan adanya hat tersebut diatas. Penyempurnaan UU Perkawinan agar terwujudnya pengaturan regulasi tersebut dibutuhkan membentuk keluarga yang bahagia, kekal, dan sejahtera ${ }^{19}$.

Regulasi mengenai Perkawinan pasal 46 Ayat (1) dan (2). Dalam ayat (1) menyatakan suatu kewajiban anak yang seyogyannya menghormati orang tua dan mentaati kehendak orang tua, selain itu ayat (2) Jika anak telah dewasa, anak wajib memelihara menurut kemampuannya,

19 Naskah akademik Undang-Undang Nomor 1 Tahun 1974 tentang Perkawinan orang tua dan keluarga dalam garis lurus keatas, bila orang tua itu memerlukan bantuannya ${ }^{20}$ regulasi perundang undangan yang terkait dengan ketentuan diatas yaitu regulasi KUHPerdata Pasal 321 yang mengambarkan mengenai anak yang memiliki kewajiban untuk menafkkahi kedua orang tuanya dan para keluarga sedarah dalam garis keatas, apabila kedua orang tua dan saudaranya dalam keadaan miskin. $^{21}$

Dengan melihat kondisi akhir akhir ini dampak dari penerapan beberapa pasal yang tidak memberikan kepastian hukum ini diakibatkan kerena pasal tersebut multitafsir misalnya mengenai ukuran kedewasaan anak, apa saja bentuk pemeliharaan orang tua yang wajib dilaksanakan anak, dan serta bagaimana sanksi atau akibat hukum jika melanggarnya. Atau anak tidak laksanakan kewajibannya dalam mememlihara orang tuannya $^{22}$. dengan Tidak adanya konseuensi hukum yang di lahirkan dalam

${ }^{20}$ Undang-Undang Nomor 1 Tahun 1974 tentang Perkawinan pasal 46 Ayat (1) dan (2). Dalam ayat (1) Hukum Perdata
${ }_{22}$ Memberikan gambaran mengenai, biaya
pemeliharaan yang dikenal dalam regulasi
Perkawinan merupakan biaya pemeliharaan kepada
orang tua kepada anaknya, bukan sebaliknya.,
https://www.hukumonline.com/klinik/detail/ulasan/
lt559f63ab58fbe/kewajiban-anak-memelihara-
orang-tua-setelah-dewasa diakses pada tanggal 25
juli 2020, pukul 16:00 wib. 21 Pasal 321 Kitab Undang-Undang 
pasal ini juga memberikan kehampaan dalam hukum itu sendiri.

Jika di konsepsikan arti "memelihara" menurut kamus besar bahasa Indonesia yaitu menjaga dan merawat secara baik baik, artinya adanya kewajiban memelihara kesehatan dan memelihara orang tua. di artikan bahwa memelihara termasuk nafkah. Dalam regulasi perUndang Undangan Perkawinan memberikan kewajiban kepada anak wajib memelihara kedua orang tuanya akan tetapi ini dapat di lakukan tergantung dari kemampuan anak, oleh karena itu muatan dari regulasi UndangUndang tersebut ada kelemahan dan karena ada pengecualian anak dapat lepas dari tanggungjawab melaksanakan kewajiban terhdap orang tuanya $^{23}$

Ernawati berpendapat bahwa arti "memelihara" dalam pasal 46 ayat ( 2 ) dari regulasi UndangUndang Perkawinan adalah sebagai berikut: Pertama, sesungguhnya pemberian nafkah kepada orang tua merupakan hal pokok yang berarti wajib atas anak artinya konsekuensi wajib. Kedua, apabila seorang anak

23 Charisa Yasmine, Pelaksanaan Kewajiban Anak Terhadap Orang Tua Studi Kasus Unit Pelaksana Teknis Pelayanan Sosial Tresna Werdha (Pstw) Khusnul Khotimah Pekanbaru Ditinjau Dari Undang-Undang Nomor 1 Tahun 1974 Tentang Perkawinan, JOM Fakultas Hukum Universitas Riau Volume IV Nomor 2, Oktober 2017, hlm 3 tersebut kaya, maka anak wajib dengan segera memberi nafkah kepada kedua orangtuanya, karena pemberian nafkah kepada orang tua itu bukanlah berarti menunggu sampai orang tua tersebut miskin (tidak mampu),. Ketiga, seorang anak itu miskin (tidak mampu) bukan berarti anak dianggap lepas dari tanggung jawab menjalankan kewajiban memberi nafkah kepada kedua orang tuanya tetapi anak tetap berusaha dan menghormati kedua orang tuanya dengan baik serta melakukan berbagai tindakan untuk dapat membahagikan orang tuannya ${ }^{24}$

Kepada semua anak memiliki bentuk kewajiban dan tanggung jawab terhadap orang tuanya yang telah merawat, memeliharan dan membesarkan dan mengasuhnya dari kecil hingga tumbuh mejdi dewasa. Untuk itu pada saat orang tua sudah memasuki lanjut usia atau sudah tidak muda lagi, banyak hal yang seyogyanya dilakukan anak. Dengan memberikan berbagai bentuk perhatian, kasih sayang, cinta kasih, serta menjaga kesehatan sampai pada tingkah lakunya di usia senja dari segala hal yang bisa menyakitinya. Dengan cara inilah anak akan dapat menciptakan keluarga yang utuh, makmur, sejahtera dan penuh kasih

${ }^{24}$ Ernawati, Kewajiban Anak Memberi Nafkah Kepada Orang Tua Menurut Hukum Islam, Jurnal Ilmu Hukum, Fakultas Hukum Universitas Esa Unggul, Jakarta, Forum Ilmiah Vol XII No 1 Januari 2015, hlm 5 
sayang serta akan timbul keseimbangan antar anak dan orang tua itu sendiri. Dengan adanya hak dan kewajiban yang di berikan kepada setiap anak dan orang tua, maka hidup menjadi lebih netral, berimbang, dan fair ${ }^{25}$. Namun, kenyataan yang tidak bisa di hindari adalah fenomena-fenomena marak seorang anak menyeret orang tua kandungnya ke meja hijau dengan berbagai alas an mulai alas an ekonomi dan sebagainya, berbagai bentuk kelemahan pun terlihat dari regulasi perundang undangan Perkawinan pasal 46 Ayat (1) dan (2) meliputi belum terikat oleh daya gravitasi, dan belum melekat untuk kemudian digunakan mengatur atau menciptakan ketertiban keamanan dan keyamanan di tengah masyarakat. Selain itu regulasi perkawinan masih diruang hampa hokum dan belum mampu memenuhi kualifikasinya untuk memenuhi tujuan hukum itu sendiri, yaitu keadilan, kemanfaatan dan kepastian. Tujuan hukum tersebut sekaligus menjadi daya gravitasi untuk mengikat atau melekatkan hukum terhadap situasi sosialnya yang terjadi di tengah masyarakat $^{26}$

25 Umar Shihab, Kontekstualitas AlQur'an Kajian Tematik Atas Ayat-ayat Hukum dalam AlQur'an, cet III, Jakarta, Penamadani, 2005, hlm 129

26. Muhammad Syukri Albani Nasution, M.A. cs., Hukum Dalam Pendekatan Filsafat, Jakarta, Kencana, 2016, hlm.287
Konsep pemenuhan dan penghormatan dan pemeliharaan orang tua yang di taungkan dalam regulasi undang undang melahirkan hak dan kewajiban, regulasi ini secara tidak langsung memberikan hak kepada setiap orang tua yang kemudian haknya di jamin oleh undang undang akan untuk itu hak yang di lahirkan diperhatikan sifat isi ketentuan hukum itu dalam memahami hukum, dilihat dari segi moral dan susila bangsa. Serta adanya perhatian akan pelaksanaan hukum dilihat dari susila dan moral rakyat yang luhur dalam memahami hukum. Ringkasnya, kualitas susila dan moral dari pelaksana hukum yang memutus atau melaksanakan hukum. HAM di Indonesia secara yuridis telah diatur dan dijamin. Aturan dan jaminan tersebut dapat dilihat dalam berbagai aturan hukum positif negara Republik Indonesia. ${ }^{27}$

\section{Problematika gugatan anak terhadap} orang tua di pengadilan di tinjau dalam perpektif hukum dan moralitas.

Moralitas merupakan suatu sikap mengenai baik buruknya seseorang yang di terima mengenai perbuatan di tengah masyarakat, Salah satu problematika

\footnotetext{
${ }^{27}$ Wibowo Alamsyah, Perlindungan Hak Asasi Manuasia Dalam Penangkapan dan Penahanan Dalam Proses Penyidikan, Disertasi, Makasar, Program Pascasarjana, Unhas, 2004, hlm 77
} 
hilangnya moralitas anak terhadap orang tua adalah mengenai lemahnya nilai nilai Pendidikan moral anak di dalam Pendidikan formal maupun Pendidikan non formal dalam lingkungan anak. Berbagai kenderungan ini muncul bukan tanpa alasan mengigat jika melihat Pendidikan yang hingga hari ini di terapkan hanya menekankan pada ilmu pengetahuan dan sains sehingga banyak aspek yang di lupakan dalam Pendidikan di Indonesia khususnya Pendidikan moralitas. Aspek tidak adanya Pendidikan moral dalam Pendidikan ini memiliki kecendungan melahirkan potensi tidak adanya sikap moralitas dalam diri anak yang nantinya menjadikan anak tersebut bermutu secara ilmu pengetahuan dan memiliki perilaku yang menjunjung tinggi nilai nilai luhur (moralitas).ini dilakukan sebagai upaya mewarikan Pendidikan yang menjungjung nilai nilai luhur. Sejalan dengan hal ini Rinehart berpendapat bahwa pentingnya mewarisi generasi muda untuk membangun bangsa, menunjukkan secara jelas perlunya pendidikan yang bermutu. Adanya ajakan dari para politisi dan pihak pemerintah untuk membangun bangsa ini, tidak akan dapat terealisasikan tanpa didukung oleh ketersediaan sistem pendidikan yang bermutu. Berbagai ajakan dan slogan tentang keberpihakan para politisi dan pihak-pihak tertentu yang tidak bertanggung jawab terhadap pendidikan merupakan kebohongan besar, jika tidak ada kesungguhan dan niat baik yang mengarah pada peningkatan kualitas pendidikan yang sungguh-sungguh bagi generasi muda sebagai penerus bangsa, sejalan dengan hal tersebut Daulat P. Tampubolon berpendapat bahwa "Kebohongan yang paling mendasar ialah apabila kita tidak mewariskan sistem pendidikan bermutu yang dapat memperlengkapi generasi muda agar mampu membangun bangsa dan negara ini untuk menghadapi tantangan zaman di masa datang. Disadari sepenuhnya dengan sistem pendidikan bermutu, generasi muda, khususnya para pemimpin penerus, akan mampu mengemban tanggung jawab berat itu ${ }^{28}$.

Selain itu Pembahasan tentang hukum pada hakikatnya tidak dapat dilepaskan dengan pembahasan terhadap aspek lainnya yaitu aspek moral dan keadilan, hukum juga dapat dilihat dari dimensi teori maupun dimensi praksis. Sehingga dikenal adanya ilmu hukum dogmatik, hukum praksis, hukum yang bertujuan bagi pengembangan ilmu pengetahuan (teori hukum), maupun hukum digunakan sebagai sarana penyelesaian sengketa yang

${ }^{28}$ Tampubolon, Daulat P. 2001. Perguruan Tinggi Bermutu: Paradigma Baru Manajemen Pendidikan Tinggi Menghadapi Tantangan Abad ke-21. Jakarta : PT. Gramedia Pustaka Utama, hlm 345 
ada di masyarakat ${ }^{29}$ jika melihat regulasi Perkawinan pasal 46 Ayat (1) dan (2) sudah memberikan gambaran yang mengadung nilai nilai moralitas akan tetapi tidak di dukung dengan pasal lainnya sehingga sehingga menimbulkan berbagai polemic atau fenomena di tengah masyarakat. Tidak hanya itu regulasi merujuk pada UU Perkawinan, kewajiban anak yang telah dewasa untuk memelihara orang tuanya juga terdapat dalam regulasi mengenai Penghapusan Kekerasan Dalam Rumah Tangga ("UU PKDRT") yang mengatakan bahwa setiap orang dilarang menelantarkan orang dalam lingkup rumah tangganya, padahal menurut hukum yang berlaku baginya atau karena persetujuan atau perjanjian ia wajib memberikan kehidupan, perawatan, atau pemeliharaan kepada orang tersebut, pasal ini juga mengambarkan tidak adanya konsekensi hukum sehingga jaminan akan kepatian hukum tidak tercapai.

Fenomena-fenomena yang marak akhir akhir ini mengenai seorang anak mengugat orang tua kandungnya ke meja hijau. Ada beberapa fenomena lunturnya moralitas yang meliputi beberapa perkara antara lain sebagai berikut:

${ }^{29}$ H. L. A. Hart, The Concept of Law", Oxford: Oxford University Press, 1994 edisi kedua, hlm.13.
1. Anak polisikan ibu kandung di Demak atas dugaan KDRT, Seorang ibu berinisial S (36) dilaporkan anaknya yang berinisial A (18) atas dugaan Kekerasan Dalam Rumah Tangga (KDRT)..

2. Nenek berusai 78 tahun digugat 3 anaknya berkaitan dengan tanah warisan $\mathrm{Hj}$ Daminah (78) asal Banyuasin, Sumater Selatan digugat oleh tiga anak kandungnya, Mila Katuarina, Apri Lina dan Hera Wati, gegara warisan. Ketiga anaknya tersebut meminta bagian harta atas tanah yang telah terjual.

3. Tak terima sewa lahan warung dibatalkan, anak gugat orang tuanya

RE Koswara (85), pria asal Kecamatan Cinambo Kota Bandung hadir di persidangan Pengadilan Negeri Bandung, Kasus anak gugat orang tua juga terjadi di Bandung. Pengadilan Negeri Kelas 1A Khusus Bandung menggelar sidang gugatan yang dilayangkan anak kepada orang tuanya Gugatan tersebut dikarenakan Denen tidak terima perjanjian sewa lahan warungnya dibatalkan oleh Koswara..

4. Gara-gara mobil Fortuner, anak menggugat ibu kandungnya terjadi di Semarang, Jawa Tengah, dimana Dewi Firdaus (52) digugat oleh 
anaknya yang bernama Alfian

Prabowo (25) karena mobil Fortuner.

5. Anak gugat ibunya gara-gara minta hak sebagian tanah Seorang ibu bernama Ramisah (67) digugat anak kandungnya bernama Maryanah (45) di Pengadilan Negeri Kendal, Jawa Tengah gegara sang anak meminta hak sebagian tanah. ${ }^{30}$.

Dari berbagai fenomena diatas muncul dikarena berbagai factor salah satunya adanya pergaulan sosial dan kurang memahaminya sikap baik buruknya perilaku atau tindakan hokum yang di lakukan untuk itu perlunya penekana pada pembagunan sikap dan peningkatan akan kualitas system Pendidikan di Indonesia khususnya Pendidikan moralitas dan Pancasila, dan di sebabkan adanya Regulasi Perkawinan pasal 46 Ayat (1) dan (2) tidak di dukung dengan konsekuensi hukum atau regulasi pendukung sehingga regulasi ini terlihat hanya sebagai pelengkap dalam ketentuan perundang undangan. Suatu reguasi yang tidak di perkuat dengan adanya konsekuensi hukum berpotensi menimbulkan adanya ketidak pastina hukum, artinya tidak adanya kepastian norma yang dapat di

\footnotetext{
30 Sederet Kasus Anak Kandung Gugat Orang Tua di Bulan Januari 2021, https://www.kompas.tv/article/141068/sederetkasus-anak-kandung-gugat-orang-tua-di-bulanjanuari-2021?page=all, di akses pada tanggal 27 juli 2021, pukul 12:29 wib.
}

jadikan pedoman bagi masyarakat ${ }^{31}$ dengan adanya kepastian tersebut dapat dimaknai oleh masyarakat bahwa ada suatu upayah yang jelas dan dan dapat di berlakukan secara tegas dalam pemberlakun hukum di dalam masyarakat. Hal ini sebagai bentuk pencegahan agar tidak menimbulkan banyak polemic dengan adanya konsekuensi hukum yang akan dilahirkan.

Suatu regulasi yang di sahkan dan diundangkan dengan memenuhi prinsip kepastian hukum akan dapat mengatur secara jelas dan logis. Artinya regulasi Perkawinan pasal 46 Ayat (1) dan (2) jika di tari benang merahnya belum diatur secara jelas dan tegas dengan gambaran yang logis mengingat regulasi ini di buat tanpa adanya konsekuensi hukum terhadap anak yang melukan tindakan yang melanggar ketentuan ini, artinya regulasi harus pasti dan Jelas dengan maksud agar regulasi perkawinan tidak menimbulkan kebingunggan dan keragu-raguan (multitafsir) dan serta dapat di tafsirkan secara logis dan dapat menjadi suatu sistem penormaan yang ideal dan selaras dengan ketentuan atau muatan norma lainnya yang tidak berbenturan atau tidak

31 Tata Wijayanta, Asas Kepastian Hukum, Keadilan dan Kemanfaatan Dalam Kaitannya Dengan Putusan Kepailitan Pengadilan Niaga, Fakultas Hukum Universitas Gadjah Mada Yogyakarta, Jurnal Dinamika Hukum Vol. 14 No. 2 Mei 2014, hlm.219 
hyper regulasi yang anntinya dapat menimbulkan konflik norma di tengah masyarakat. Konflik norma yang ditimbulkan dari adanya ketidakpastian aturan hukum dapat berbentuk kontentasi norma, reduksi norma atau distorsi norma.dan moralitas untuk itu adanya keharmonisan dalam regulasi sangat perting dilaksanakan ${ }^{32}$ Maria S.W. Sumardjono berpendapat bahwa konsep kepastian hukum, merupakan kepastian hukum yang memerlukan tersediannya perangkat peraturan perundang-undangan yang secara operasional maupun mendukung pelaksanaannya. Serta dalam implementasinya keberadaan peraturan perundang undangan perkawinan dilaksanakan secara konsisten dan melahirkan konsekuen ${ }^{33}$ untuk itulah konsekuensi sangat di perlukan sebagai upaya membanngun penegakan hukum itu sendiri.

Tanggungjawab Penegakan Hukum terhadap Pasal 46 regulasi perkawinan

32 R. Tony Prayogo, Penerapan Asas Kepastian Hukum Dalam Peraturan Mahkamah Agung Nomor 1 Tahun 2011 Tentang Hak Uji Materiil Dan Dalam Peraturan Mahkamah Konstitusi Nomor 06/Pmk/2005 , Vol. 13 N0. 02 Juni 2016 : 191 - 202, Hlm 193

33 Maria S.W. Sumardjono, “ "Makalah disampaikan dalam seminar kebijaksanaan baru di bidang pertanahan, dampak dan peluang bagi bisnis properti dan perbankan”, Jakarta, 6 Agustus 1997, hlm. 1 dikutip dari Muhammad Insan C. Pratama, Skripsi, berjudul Kepastian Hukum dalam Production Sharing Contract, Fakultas Hukum Universitas Islam Indonesia, Yogyakarta, 2009, hlm. 14 dilaksanakan guna mencegah anak menggugat orangtua hal ini dapat dilakukan dengan merumuskan kebijakan hukum lanjutan sebagai penjabaran ketentuan Pasal tersebut, sehingga diperoleh suatu kepastian dan ketegasan hak-hak orangtua yang harus di lindungi hukum. ${ }^{34}$

Ada empat ciri pokok yang seyogyanya ditemukan bersama-sama di dalam regulasi Perkawinan yang meliputi prinsip, dasar regulasi, dan standar tingkah laku dengan berpedoman pada moral; hal ini mencerminkan indicator yang berfungsi memenuhi standar-standar moral dalam kehidupan sosial. ${ }^{35}$ Keempat ciri tersebut meliputi nilai penting (importance), .

1. Nilai penting (importance), yang pada hakekatnya regulasi perkawinan yang di anggap standar moral dipandang sebagai sesuatu yang memiliki nilai untuk diperintahkan guna memenuhi standar moral..

2. Kekebalan dari perubahan yang disengaja. Artinya regulasi atau asas atau setandar-setandar tingkah laku tidak bisa dilekati atau dilucuti status moralnya oleh keputusan arbitrer manusia, meskipun pengunaan sehari-

${ }^{34}$ Riska Andista Indriyani, Kontradiksi Antara Kewajiban Anak Kepada Orangtua Dengan Anak Menggugat Orangtua, Jurnal Privat Law Vol. VII No 2 Juli - Desember 2019, hlm 286

35 Petrus C.K.L. Bello, Hukum dan Moralitas, Gelora Aksara Pratama, Jakarta, 2012, hlm. 41 
hari konsep-konsep seperti penetapan dan penghapusan memperlihatkan bahwa hal yang sama tidak berlaku pada hukum.

3. Ciri kesengajaan dalam pelangaran moral, jika seseorang yang tindakanya, dinilai, telah melangar prinsip atau peraturan moral, berhasil memastikan bahwa hal itu tanpa disengaja dan terlepas dari semua kehati-hatian yang mungkin ditempuhnya, tindakan tersebut pun akan dimaklumi dan terbebas dari tanggung jawab moral.

4. Bentuk tekanan moral mendukungnya berwujud seruan untuk menghargai regulasi sebagai suatu bagian terpenting, Dengan demikian, tekanan moral kendati tidak secara eksklusif, yang bukan merupakan ancaman atau seruan kepada rasa takut atau kepentingan orang lain.

\section{KESIMPULAN}

1. Esensi hubungan anak dan orang tua dalam regulasi Perkawinan belum memberikan kepastian hukum mengingat belum adanya pasal pasal yang menjelaskan lebih lanjut ukuran kedewasaan anak, bentuk pemeliharaan orang tua yang wajib dilakuan anak, dan akibat hukum jika melanggarnya. Sehingga regulasi ini tidak dapat berjalan atau tidak dapat terpenuhinya suatu kepastian.

2. Problematika fenomena maraknya gugatan anak terhadap orang tua di pengadilan tidak lepas dari hilangnya moralitas anak terhadap orang tua adalah mengenai lemahnya nilai nilai Pendidikan moral anak di dalam Pendidikan formal maupun Pendidikan non formal dalam lingkungan anak, problematikan ini makin tidak terbendung di dengan tidak adanya kebijakan hukum lanjutan sebagai penjabaran regulasi Perkawinan sehingga diperoleh suatu ketegasan agar hak-hak orangtua terlindungi dan dapat meletakan kedudukan orang tua pada apa yang seharusnya di kehendaki oleh ketentuan tersebut.

\section{DAFTAR PUSTAKA}

Notohamidjojo, (1975), Soal-Soal Pokok Filsafat Hukum, Jakarta: Gumung Mulia, BPK.

Wahyu, (2005), Perubahan Sosial dan Pembangunan, Jakarta, PT Hecca Mitra Hutama.

Supriadi, (2002), Etika dan Tanggung Jawab, Jakarta, Sinar Grafika,.

Soerjono Soekanto, (1983), Faktor-Faktor yang Mempengaruhi Penegakkan Hukum, Jakarta, CV Rajawali,.

Philipus M Hadjon dan Tatiek Sri Djatmiati, (2016), Argumen Hukum, Surabaya, Gadjah Mada University Press, Cetakan Ke 7,. 
Johnny Ibrahim, (2010), Teori dan Metodologi Penelitian Hukum Normatif, Malang, Banyumedia,.

Peter Mahmud Marzuki, (2005) Penelitian hukum, Edisi Revisi, Jakarta, Kencana,

Charisa Yasmine, Pelaksanaan Kewajiban Anak Terhadap Orang Tua Studi Kasus Unit Pelaksana Teknis Pelayanan Sosial Tresna Werdha (Pstw) Khusnul Khotimah Pekanbaru Ditinjau Dari UndangUndang Nomor 1 Tahun 1974 Tentang Perkawinan, JOM Fakultas Hukum Universitas Riau Volume IV Nomor 2, Oktober 2017

Ernawati, Kewajiban Anak Memberi Nafkah Kepada Orang Tua Menurut Hukum Islam, Jurnal Ilmu Hukum, Fakultas Hukum Universitas Esa Unggul, Jakarta, Forum Ilmiah Vol XII No 1 Januari 2015

Umar Shihab, Kontekstualitas Al-Qur'an Kajian Tematik Atas Ayat-ayat Hukum dalam AlQur'an, cet III, Jakarta, Penamadani, 2005

Muhammad Syukri Albani Nasution, M.A. cs., Hukum Dalam Pendekatan Filsafat, Jakarta, Kencana, 2016.

Wibowo Alamsyah, Perlindungan Hak Asasi Manuasia Dalam Penangkapan dan Penahanan Dalam Proses Penyidikan, Disertasi, Makasar, Program Pascasarjana, Unhas, 2004.

Tampubolon, Daulat P. 2001. Perguruan Tinggi Bermutu: Paradigma Baru Manajemen Pendidikan Tinggi Menghadapi Tantangan Abad ke-
21. Jakarta, PT. Gramedia Pustaka Utama.

H. L. A. Hart, The Concept of Law", Oxford, Oxford University Press, edisi kedua, 1994

Petrus C.K.L. Bello, (2012) .Hukum dan Moralitas, Gelora Aksara Pratama, Jakarta,

Roni Sulistyanto Luhukay, Penghapusan Izin Lingkungan Kegiatan Usaha Dalam Undang Undang Omnibus Law Cipta Kerja Jurnal MetaYuridis, No. P-ISSN : 2614-2031 / NO. E-ISSN : 2621-6450, Fakultas Hukum Universitas PGRI Semarang.

Roni Sulistyanto Luhukay,dan Jaelani, Abdul Kadir. Penataan Sistem Peraturan Perundang-Undangan Dalam Mendukung Penguatan Konstitusi Ekonomi Indonesia. Jatiswara, volume. 34, no. 2 , july 2019. ISSN 2579-3071.

Riska Andista Indriyani Anjar Sri Ciptorukmi Nugraheni, Kontradiksi Antara Kewajiban Anak Kepada Orangtua Dengan Anak Menggugat Orangtua, Jurnal Privat Law Vol. Vii No 2 Juli - Desember 2019.

Tata Wijayanta, Asas Kepastian Hukum, Keadilan dan Kemanfaatan Dalam Kaitannya Dengan Putusan Kepailitan Pengadilan Niaga, Fakultas Hukum Universitas Gadjah Mada Yogyakarta, Jurnal Dinamika Hukum Vol. 14 No. 2 Mei 2014.

R. Tony Prayogo, Penerapan Asas Kepastian Hukum Dalam Peraturan Mahkamah Agung Nomor 1 Tahun 2011 Tentang Hak Uji Materiil Dan Dalam Peraturan Mahkamah Konstitusi Nomor 
06/Pmk/2005, Vol. 13 N0. 02 Juni 2016.

Maria S.W. Sumardjono, "Kepastian Hukum dalam Pendaftaran Tanah dan Manfaatnya Bagi Bisnis Perbankan dan Properti, "Makalah disampaikan dalam seminar kebijaksanaan baru di bidang pertanahan, dampak dan peluang bagi bisnis properti dan perbankan", Jakarta, 6 Agustus 1997, hlm. 1 dikutip dari Muhammad Insan C. Pratama, Skripsi, berjudul Kepastian Hukum dalam Production Sharing Contract, Fakultas Hukum Universitas Islam Indonesia, Yogyakarta, 2009.

Riska Andista Indriyani, Kontradiksi Antara Kewajiban Anak Kepada Orangtua Dengan Anak Menggugat Orangtua, Jurnal Privat Law Vol. VII No 2 Juli - Desember 2019.

Tedy Sudrajat, "Perlindungan Hukum Terhadap Hak Anak Sebagai Hak Asasi Manusia Dalam Perspektif Sistem Hukum Keluarga di Indonesia", Kanun Jurnal Ilmu Hukum, Nomor 54, Tahun XIII (Agustus 2011), 123, diakses tanggal 16 Oktober 2017, http://www.jurnal.unsyiah.ac.id/ka nun/article/do wnload/6245/5150, diakses pada tanggal 24 juli 2021, pukul 16:30 wib.

Marcelia Oktavia Gosal Yuwono Prianto, Perlindungan Hukum Terhadap Lanjut Usia Yang Mengalami Kekerasan Psikologis Dan Finansial, Jurnal Era Hukum, Volume 2, No. 2, Oktober 2017, hlm 295

Naskah akademik Undang-Undang Nomor 1 Tahun 1974 tentang Perkawinan
Undang-Undang Nomor 1 Tahun 1974 tentang Perkawinan

Kitab Undang-Undang Hukum Perdata

Naskah kademik Rancangan undang undang tentang hukum acara perdata, https://www.bphn.go.id/data/docu ments/naskah_akademik_ruu_tenta ng_hukum_acara_perdata.pdf, diakses pada tanggal 24 juli 2021, pukul 16:30 wib

Sindonews, maraknya anak gugat orang tua di pengadilan dengan berbagai masalah ekonomi, Https://Daerah.Sindonews.Com/Re $\mathrm{ad} / 313110 / 701 /$ Marak-AnakGugat-Orang-Tua-Dosen-UnpadSecara-Norma-Dan-Hukum-TidakBoleh-1611558095, diakses pada tanggal 25 juli 2021 pukul 16:30 wib

Fenomena anak gugat orang tua ke pengadilan dan bukti lunturnya moralitas, https://www.pikiranrakyat.com/bandung-raya/pr01293982/fenomena-anak-gugatorang-tua-ke-pengadilan-buktilunturnya-moralitas-420181, dikases pada tanggal 23 juli 2021, puhuk 12:21 wib

Sepanjang penelusuran kami, biaya pemeliharaan yang dikenal dalam UU Perkawinan adalah biaya pemeliharaan orang tua kepada anaknya, bukan sebaliknya. Bapak yang bertanggung jawab atas semua biaya pemeliharaan dan pendidikan yang diperlukan anak itu; bilamana bapak dalam kenyataan tidak dapat memenuhi kewajiban tersebut, Pengadilan dapat menentukan bahwa ibu ikut memikul biaya tersebut. Jadi, pada dasarnya tidak ada dasar hukum yang secara jelas mewajibkan anak 
Vol. 5, No. 1, Februari 2022 / P-ISSN: 2622-9862 / E-ISSN: 2622-707X

yang telah dewasa untuk menanggung biaya pemeliharaan orang tuanya, https://www.hukumonline.com/klin $\mathrm{ik} /$ detail/ulasan/lt559f63ab58fbe/ke wajiban-anak-memelihara-orangtua-setelah-dewasa diakses pada tanggal 25 juli 2020, pukul 16:00 wib 